\title{
Uzaktan Algılama Verileri ile Uluslararası Suların İzlenmesi
}

\author{
Gordana KAPLAN ${ }^{1 *}$, Zehra YIGIT AVDAN ${ }^{2}$, Ugur AVDAN $^{1}$, Tatjana JOVANOVSKA ${ }^{3}$
}

Öz

Su kaynaklarının pek çoğu iki ya da daha fazla ülke tarafından paylaşılmaktadır. Gelişmemiş ve gelişmekte olan bazı ülkeler için su yönetiminden kaynaklanan anlaşmazlıklar çok büyük sorunlar meydana getirebilir. Bundan dolayı, sınır aşan su kaynaklarının sürdürülebilirliğinin sağlanabilmesi için sürekli izlenmesi gerekmektedir.

Son yıllarda uzaktan algılama verileri ile su alanlarının izlenmesi başarılı bir şekilde yapılmaktadır. Bu çalışmada, Kuzey Makedonya ile Yunanistan arasında paylaşılan Dojran Gölünün otuz yıllık değişimleri uzaktan algılama teknikleri kullanılarak incelenmiştir. Landsat görüntülerinden elde edilen endeksler gölün izlenmesi için kullanılmıştır. Su seviyesi ölçüm istasyonundan elde edilen veriler ile karşılaştırıldığında, sonuçlar 0,79 'dan yüksek determinasyon katsayısı göstermiştir. Çalışmanın sonucunda göl için en kritik yıl 2002 iken, 2017 yılında 1986 yılındaki su seviyesine ulaştığı görülmüştür.

Sürdürülebilirlik ve eşitlik içeren uzun vadeli su planlama ve yönetimine yönelik yeni yaklaşımlar, su hakkı konusundaki ihtilafların azaltılması ve özellikle paydaş olan ülkeleri de etkileyebilecek ekolojik ve çevresel felaketlerin önlenmesi için gereklidir.

Bu tür uluslararası sınır aşan su kütlelerinin ortak kullanımı, paydaş ülkeler için su kıtlığına ve ekolojik sorunlara direnç sağlayabilir. Bu nedenle, uzaktan algılama teknolojilerini kullanarak su kütlelerinin belirlenmesi ve gerekli ölçümlerin yapılması büyük önem taşımaktadır. Bu çalışma böyle bir değişimin yüksek doğrulukla belirlenebileceğinin önemli bir örneğidir.

Anahtar Kelimeler: Uzaktan Algılama, Su Alanı, Jeopolitik, Uluslararası İlişkiler.

\section{Monitoring Shared International Waters with Remote Sensing Data}

\begin{abstract}
Many freshwater bodies are shared by two or more countries. Managing shared water can cause conflicts over freshwater rights and may become a brake on development for some struggling nations. Frequent water bodies monitoring is a crucial part of their sustainable management.
\end{abstract}

As remote sensing data can be useful in monitoring water bodies, in this study, three-decade changes of a shared lake between North Macedonia and Greece, Dojran Lake, have been investigated using remote sensing techniques. For that purpose, several indices retrieved from the Landsat have been used for monitoring the Lake. The results from the analyses have been compared with the data from a water level gauging station, and the results showed a strong coefficient of determination higher than 0.79. Results show that the most

\footnotetext{
${ }^{1}$ Earth and Space Institute, Eskisehir Technical University, Eskisehir/Turkey

2 Department of Environmental Engineering, Eskisehir Technical University, Eskisehir/Turkey

${ }^{3}$ Institute of Security, Defense and Peace, Ss. Cyril and Methodius University, Skopje/North Macedonia

* İlgili yazar / Corresponding author: kaplangorde@gmail.com

Gönderim Tarihi / Received Date: 10.09.2019

Kabul Tarihi / Accepted Date: 29.05.2020
} 
critical year for the Lake has been 2002 when it started recovering and by the year of 2017 has gained its water area as in 1986. New approaches to long-term water planning and management that incorporate principles of sustainability and equity are required for lowering the conflicts over water rights, and especially to avoid ecological and environmental catastrophes that may affect both of the sharing countries.

The joint use of such international cross-border water bodies can create resilience to water scarcity or ecological problems for each country. Therefore, it is of great importance to determine these water bodies using remote sensing technologies and to take necessary measurements. This study is an example that such an event can be determined with high accuracy.

Keywords: Remote Sensing, Water Area, Geopolitics, International Relations.

\section{INTRODUCTION}

The concept of security, which in international relations is more prominent to military relations, has expanded in terms of content and scope. In this context, new non-military elements that pose a threat to peace and security are also included in the scope of security. One of these elements is environmental problems, from where the concept of environmental security comes. Thus, environmental problems have come to the forefront in the security perceptions and policies of the states. Water resources constitute one of the critical issues within the scope of environmental security. Water, which is an indispensable resource for life, has become a serious global problem due to many factors such as global warming and drought. With the geographical fact that many sources of freshwater are shared by two or more nations, has become an agenda item that must be dealt with in the discipline of international relations. Conflicts over water rights may become a brake on development for some struggling nations; thus, water bodies monitoring as a crucial part of their sustainable management needs to be done frequently.

Geospatial and remote sensing analysis are widely used for water bodies monitoring, and the results can be helpful for decision making and mitigate drought impacts (Elkollaly, Khadr, \& Zeidan, 2017; Khadr, 2017; Sigdel \& Ikeda, 2010). Remote sensing data may be the only source of providing spatially distributed data at multiple scales and on a consistent and timely basis. Remote sensing instruments and techniques provide information for soil and water studies related to ecosystem sustainability, drought mitigation, water balance, and water quality and land use and land cover changes (Ustin, 2004). Monitoring water levels and discharges with remote sensing data has been done with radar altimetry (Bogning et al., 2018), or altimetry data obtained from ENVISAT and ERS-2 satellites (Munyaneza, Wali, Uhlenbrook, Maskey, \& Mlotha, 2009), multiple satellite altimetry data and Moderate Resolution Imaging Spectroradiometer (MODIS) for estimating continental river basin discharges (Sichangi et al., 2016). Also, optical remote sensing imagery like Landsat have been used for water bodies monitoring (Gleason \& Smith, 2014; Gleason, Smith, \& Lee, 2014). A combination of optical and radar images has also been used for the extraction of water bodies (Nakmuenwai, Yamazaki, \& Liu, 2017). All of the mentioned studies use measuring from gauging stations to compare the obtained results.

Landsat legacy has been widely used as a source of data. Starting from 1984, Landsat 5 has been the longest-operating satellite that stopped working in 2011 and has provided many satellite images today used for time-series researchers (USGS). Remote sensing data are also taking part in drought monitoring using different indexes. According to Nemani and Running (Nemani \& Running, 1989), combining lands surface temperature and vegetation indices are of great interest for drought monitoring. Orhan et al. (Orhan, Ekercin, \& Dadaser- 
Celik, 2014) used Land Surface Temperature (LST), Normalized Difference Vegetation Index (NDVI), Vegetation Condition Index (VCl) and Temperature-Vegetation Index (TVX) for monitoring drought in the Salt Lake, Turkey. Keshavaraz et al. used Soil Wetness Index (SWI) to evaluate soil moisture deviation as an indicator of agricultural drought (Keshavarz, Vazifedoust, \& Alizadeh, 2014). Other researchers used Normalized Difference Water Index (NDWI) and other indices for water area changes and drought monitoring (Gao, Gao, \& Chang, 2011; Omute, Corner, \& Awange, 2012). NDWI can also be used for calculating lost water areas. The drought problem caused by climate change has made it necessary to ensure the effective management of water resources.

In this paper, three-decade changes of a shared lake between North Macedonia and Greece, Dojran Lake, have been investigated using remote sensing data and techniques. Also, the correlation between NDWI, NDVI, LST, and measurements retrieved from gauging station as a more straightforward method for drought and water level monitoring of Dojran Lake has been investigated. The indices were calculated from Landsat TM, ETM+, and TIRS. The monitoring has been made in the period 1986 to 2017 in the summer period using 29 satellite images taken in July and August. Also, the results have been compared with data from the water level gauging station Nov Dojran for the period of 1986-2010.

\section{MATERIAL AND METHODS}

\subsection{Study area and Data}

Dojran Lake is one of the smallest lakes of the Balkans located in the southeastern part of North Macedonia shared by Macedonia and Greece, and it represents a significant hydrological resource for the surroundings. The water surface of the Lake is approximately $42 \mathrm{~km}^{2}$ at an elevation of $147.4 \mathrm{~m}$ above sea level (asl), and more than $63 \%$ belongs to North Macedonia. The watershed length is $33.5 \mathrm{~km}$ on the North Macedonian side and 46.3 on the Greek side (Figure 1) (Bonacci, Popovska, \& Geshovska, 2015). The Lake is fed by creeks, small rivers, and springs, with most of the runoff coming from the Belasica Mountain (Zhang, Reed, Wagner, Francke, \& Levkov, 2014). This tectonic Lake is an important part of the region both for agriculture and tourism, and it is attracting many tourists during the summer. In this study, a $350 \mathrm{~m}$ buffer from the most prominent form from 1986 to 2017 has been taken as a study area.

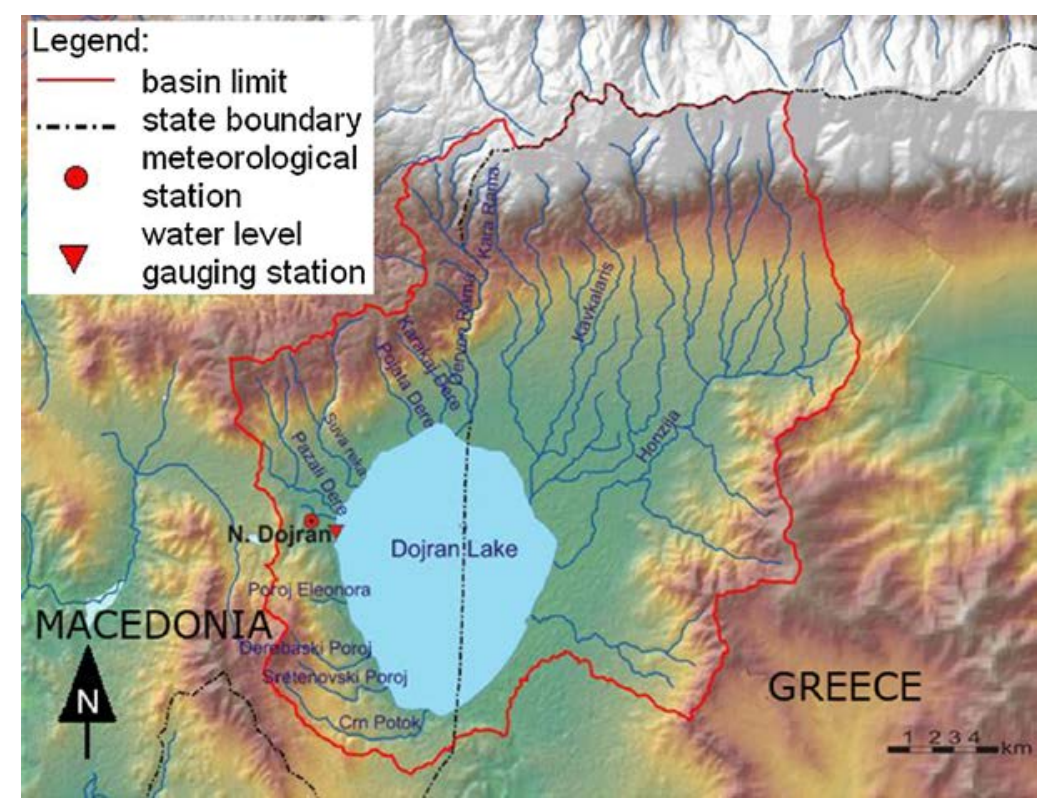

Figure 1. Dojran`s Lake watershed (Bonacci et al., 2015) 
For the analyses, satellite images from Landsat TM, ETM+, and TIRS have been used. Landsat 4-5 TM data has been used for the period from 1986 to 2011, Landsat 7 ETM+ data has been used for the period from 1999 to 2015, and Landsat 8 TIRS/OLI data were used from 2013 to 2017. It should be mentioned that SLC correction has not been carried out on the Landsat- 7 images since the study area has not been affected by the error. The satellite images were downloaded from USGS web page. Total of 29 satellite images with Path 184 and Row 81 were processed. The dates of the satellite images were chosen in the summer period of late July and August (Table 1).

Table 1. Details for the used satellite images

\begin{tabular}{|c|c|c|c|}
\hline Satellite & Day & Month & Year \\
\hline Landsat 5 & 1 & 8 & 1986 \\
\hline Landsat 5 & 19 & 7 & 1988 \\
\hline Landsat 5 & 12 & 8 & 1990 \\
\hline Landsat 7 & 28 & 7 & 1999 \\
\hline Landsat 7 & 15 & 8 & 2000 \\
\hline Landsat 7 & 2 & 8 & 2001 \\
\hline Landsat 7 & 5 & 8 & 2002 \\
\hline Landsat 5 & 16 & 8 & 2003 \\
\hline Landsat 7 & 9 & 7 & 2004 \\
\hline Landsat 7 & 28 & 7 & 2005 \\
\hline Landsat 5 & 23 & 7 & 2006 \\
\hline Landsat 7 & 15 & 7 & 2006 \\
\hline Landsat 5 & 26 & 7 & 2007 \\
\hline Landsat 7 & 3 & 8 & 2007 \\
\hline Landsat 7 & 21 & 8 & 2008 \\
\hline Landsat 5 & 31 & 7 & 2009 \\
\hline Landsat 7 & 23 & 7 & 2009 \\
\hline Landsat 5 & 3 & 8 & 2010 \\
\hline Landsat 7 & 11 & 8 & 2010 \\
\hline Landsat 5 & 21 & 7 & 2011 \\
\hline Landsat 7 & 14 & 8 & 2011 \\
\hline Landsat 7 & 19 & 8 & 2013 \\
\hline Landsat 8 & 11 & 8 & 2013 \\
\hline Landsat 7 & 21 & 7 & 2014 \\
\hline Landsat 8 & 19 & 7 & 2014 \\
\hline Landsat 7 & 24 & 7 & 2015 \\
\hline Landsat 8 & 2 & 8 & 2015 \\
\hline Landsat 8 & 3 & 8 & 2016 \\
\hline Landsat 8 & 6 & 8 & 2017 \\
\hline
\end{tabular}

Additionally, data from the meteorological station Nov Dojran and the water level gauging station used in Bonacci et al. (Bonacci et al., 2015) were used for comparison of the obtained results. Data from the Dojran municipality were also used in this paper taken from the municipalities' webpage (Dojran-info). 


\subsection{Methods}

In the boundaries of the study area (350-meter buffer from the border of the lake) NDWI, NDVI, and LST indices were used. The NDWI is used for delineate open water features and enhance their presence in remote sensed data. The NDWI uses reflected near-infrared radiation and visible green light helping us to distinguish the water bodies from the soil and terrestrial vegetation features (McFeeters, 1996).

$$
\mathrm{NDWI}=\frac{\text { Green-NIR }}{\text { Green+NIR }}
$$

The NDVI was also used for distinguishing the water bodies, and it was compared to the NDWI. The NDVI analyzes are usually made for vegetation mapping, but with its classification, vegetation can be easily separated from urban areas, barren lands, water bodies etc. Values for NDVI ranges from 1.0 to -1.0 ; higher values indicate a higher concentration of green vegetation. Lower values indicate non-vegetated features, such as water, barren land, ice, snow, or clouds (Sabins, 1997). The NDVI values were classified into four land-cover types. Values lower than 0 were classified as barren land or water area, values from 0 to 0.2 correspond to bared soil, values from 0.2 to 0.50 represent a mixture of soil and vegetation and values above 0.5 correspond to a fully vegetated area (Sobrino \& Raissouni, 2000). The NDVI data from the three different sensors were directly compared since there is no significant difference in their values (Li, Jiang, \& Feng, 2014).

$$
\text { NDVI }=\frac{\text { NIR-Red }}{\text { NIR+Red }}
$$

For the estimating of the LST, Plank`s method has been chosen (Artis \& Carnahan, 1982). A tool in QGIS has been used for calculating the LST from Landsat TM and ETM+. For more detailed information, see Ndossi and Avdan (Isaya Ndossi \& Avdan, 2016). The LST from Landsat TIRS was retrieved using the tool in Erdas IMAGINE (Avdan \& Jovanovska, 2016).

The results from the LST has been used to investigate the temperature behavior with the water area changing. Observations were made separately for the three different sensors; Landsat TM from 1986 to 2011, for Landsat ETM+ from 2002 to 2014 and Landsat 8 from 2013 to 2017.

The analyses were made for each satellite image. In total, 29 satellite images were processed but in the results, not all of them were taken since some of the years were overlapping. In general, images from Landsat ETM+ were used. Still, the overlapping images were compared and a significant difference hasn't been noticed. The results from the satellite images have been compared with the results taken from the water level gauging station (Bonacci et al., 2015).

\section{RESULTS AND DISCUSSION}

The NDWI analysis for 1986 - 2017 showed that starting from 1986 - 2002 the lakes area has been lowering drastically when it hits the lowest point of a $31.9 \mathrm{~km}^{2}$ from $39.2 \mathrm{~km}^{2}$ in 1986 . After 2002 the area is starting to grow, hitting record $39.6 \mathrm{~km}^{2}$ since 1986 . The NDVI results showed similar results to the NDWI results. Starting from 1986 the water area has been decreasing with the lowest point in 2002 with $32.0 \mathrm{~km}^{2}$ and then reaching its highest point in 2017 with $40.1 \mathrm{~km}^{2}$ (Figure 2). 


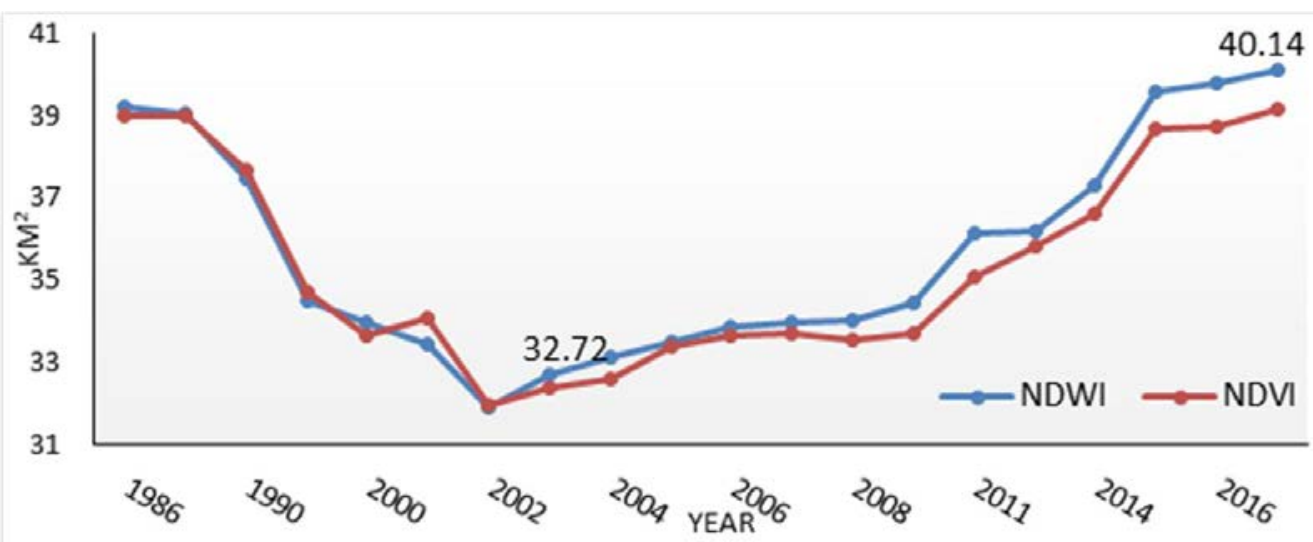

Figure 2. Time data series from NDVI and NDWI results in $\mathrm{km}^{2}$.

From the observation of Figure 2, it is obvious the similarity between them that can be noticed from the considerable high value of the correlation coefficient $R^{2}$ of 0.97 . A relation table was made for all obtain results from all satellite images (Figure 3). Both of the analyses showed 2002 as the lowest point in the data series.

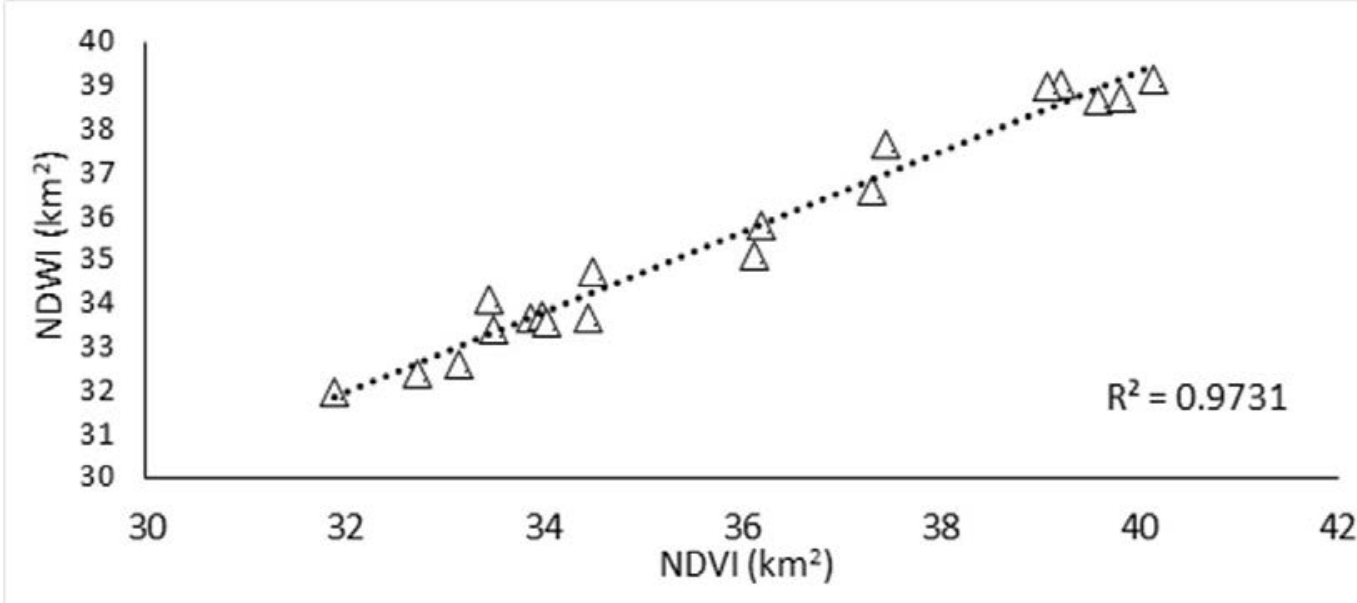

Figure 3. Relationship between NDWI and NDVI results

To decide which index bring more accurate results for water analysis, we compared our results with the results of previous researchers. Bonacci et al. (Bonacci et al., 2015) analyzed transboundary Dojran Lake mean annual water level changes using the meteorological and hydrological data obtained from Nov Dojran gauging station. The provided data are from the period 1952 - 2010. The computation was made using the overlapping dates, the period from 1896 to 2010 (Figure 4). A correlation was made between the average annual water level values and the NDWI and NDVI values (Figure 5). As expected, the NDWI has given better results than the NDVI. The reason for the expectation was the fact that in the NDVI analysis in the group of values lower than zero are also barren land, snow, and clouds. 


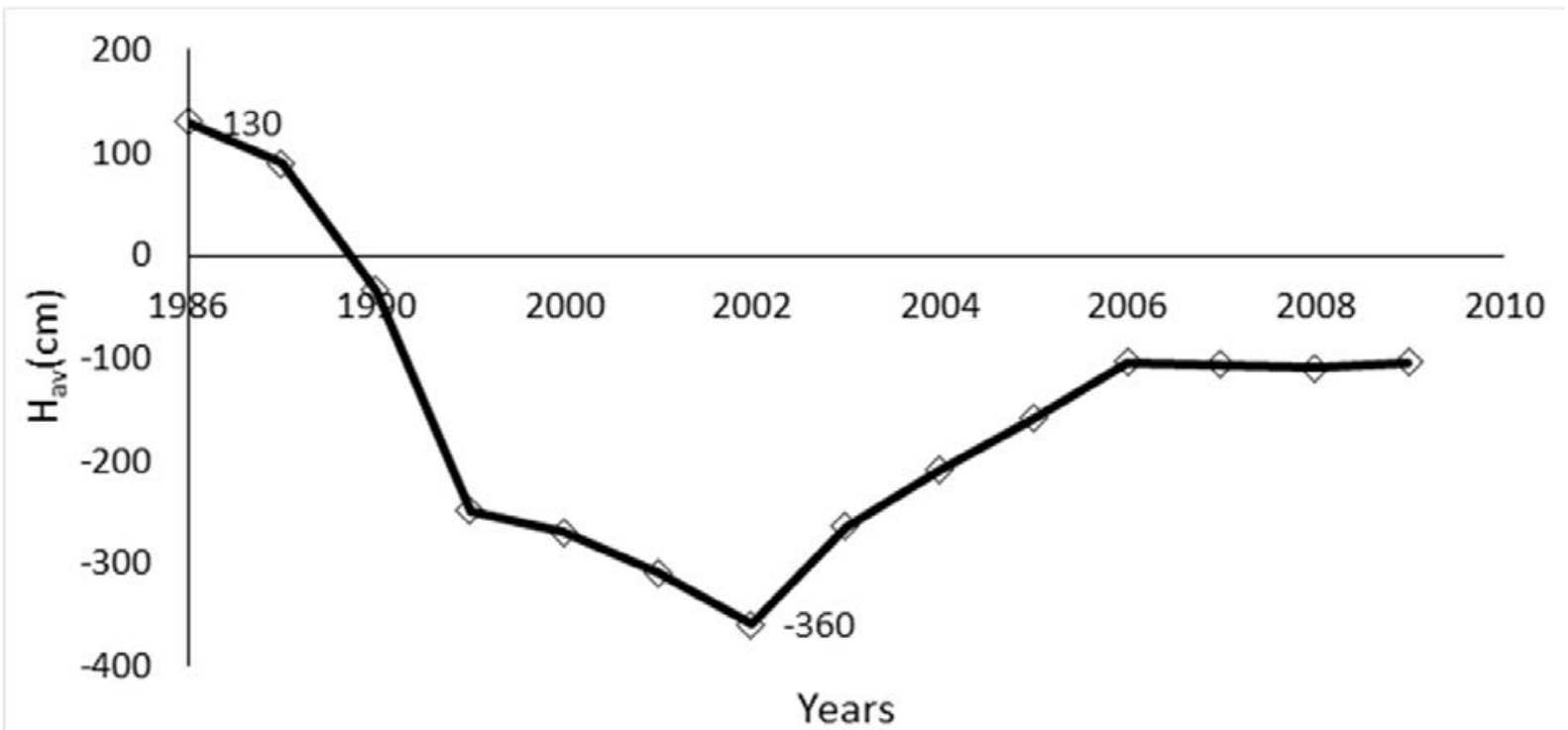

Figure 4. Time data series of average annual water levels for Dojran Lake at Nov Dojran hydrological station for the period 1986-2010.

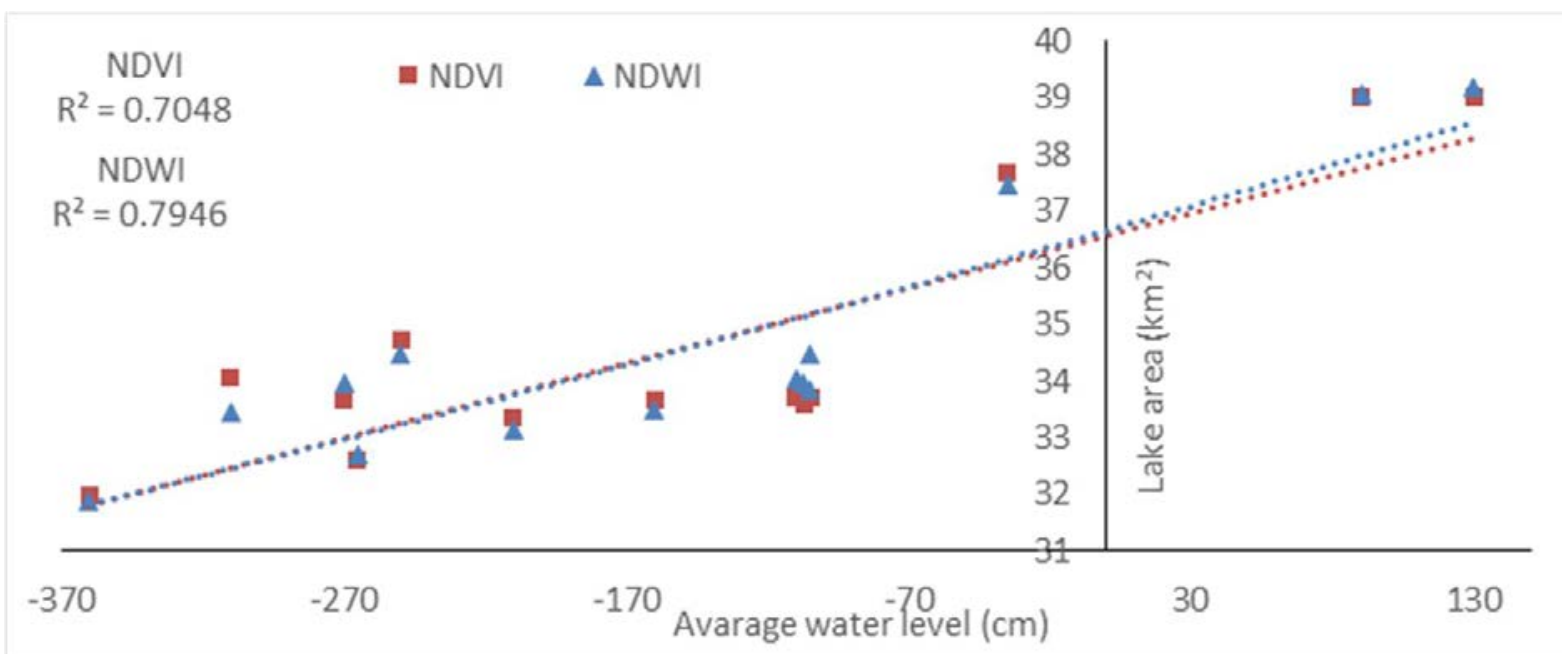

Figure 5. The correlation coefficient between the average water level and the NDWI and correlation coefficient between the average water level and the NDVI

If the water at some points is fully vegetated, the area can appear as a vegetation area instead of a water area. The correlation coefficient between the average water level and the NDWI values has a significant value of $R^{2}>0.79$, while the correlation with the NDVI values is considerably lower with $R^{2}$ of 0.70 . The relations are shown in Figure 5. From the results, it was concluded that both NDWI and NDVI could be used for water changes monitoring, but NDWI gave better results. Both indexes have reached the minimum and maximum points of the water level according to the in situ data. The significant rising of the water level after 2002, according to Dojran municipality data (Dojran-info), occurred after the activating of the hydro system Gjavato made with the project started by the government of the Republic of North Macedonia in 1999 for saving the Dojran Lake. According to the project, the hydro system with the functionality of $90 \%$ can bring $28 \times 10^{6} \mathrm{~m}^{3}$ water per year in Dojran Lake. With this amount of water, the system needs to pump water for at least 10 to 12 years, with an annual water loss of 10 to $15 \times 10^{6} \mathrm{~m}^{3}$ (Matlievska). The first water from the system started to run into the Lake in September 2002. 
In Figure 6, an NDWI map of the study area has been shown from 1986, 2002, and 2017 respectively. The difference, the decrease in 2002, and then the increase of the water are easily noticeable. Comparing the starting point, 1986, and the lowest point of the water area, 2002, the difference is easily noticeable in Figure 6.
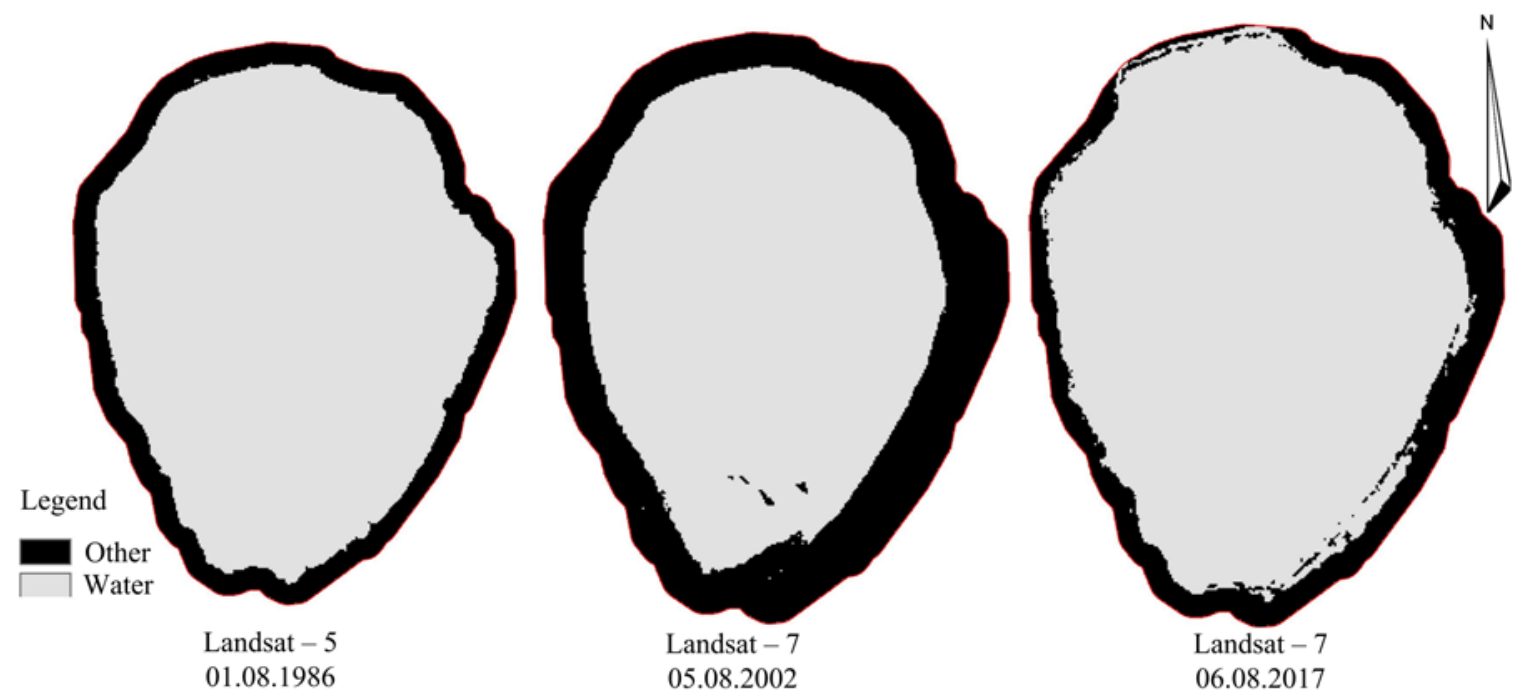

Figure 6. NDWI map of the study area from 1986, 2002 and 2017 respectively
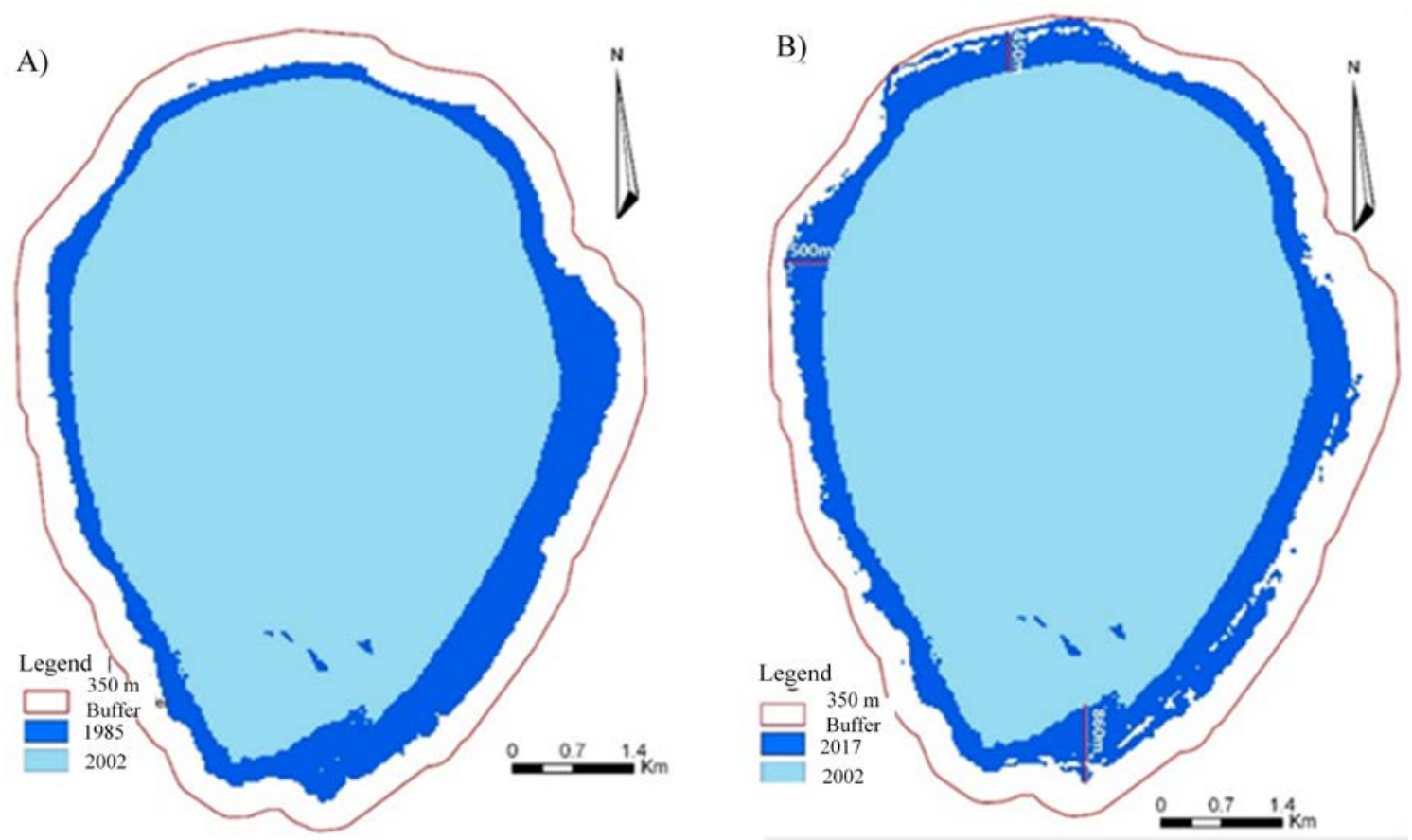

Figure 7. Comparative map of the water body retrieved from NDWI values from: a) 1986 2002 and b) $2002-2017$ 
From Figure 7, the significant drought of the Lake can be seen. According to the NDWI analysis, the water has lost more than $7 \mathrm{~km}^{2}$ water area. The most significant loss can be seen in the southern region, with the withdrawal of the water line approximately 860 meters. Also, extremely high withdrawal has been noticed in the eastern part with 750 meters. In the southern part of the study area, islands can be spotted. This is reasonable, taking into consideration the average and maximum depth of the lake (6.5 m and $10.4 \mathrm{~m}$, respectively). Also, according to the data from the gauging station, the water level was lowering from 1.5 meters in 1986 to -3.6 meters. The same comparison was made between 2002 and 2017.

From Figure 7, the improvement of the water body can be seen. The southern, northern and western parts of the Lake have been fully recovered since 1986, and there are some improvements in the eastern part. In the southern part, the improvements have come up to 860 meters' water body line, south up to 500 meters, and to the western part, the water body line has improved up to 500 meters from 2002 or 350 meters from 1986 . According to the results discussed, it can be concluded that Dojran Lake has been recovered or gain its water area back since 1986.

The LSTs from two Landsat satellite images from 2002 and 2015 were compared. While the water area results showed that the water area was smaller in 2002, the mean LST of the study area showed a slight growth of $0.5^{\circ} \mathrm{C}$ in 2015. After 2002, the water level has one of the most significant increases of $3.3 \mathrm{~km}^{3}$; however, the mean LST of the study area has decreased by $0.76{ }^{\circ} \mathrm{C}$ (Figure 8b). According to the results, it is hard to set a link between the water area decreasing and the LST.

Compared with other studies, using NDWI from Landsat images for water bodies monitoring is a competitive method besides other remote sensing data and methods. Munyaneza et. at (Munyaneza et al., 2009) achieved $R^{2}$ of 0.86 with ENVISAT data and $R^{2}$ of 0.77 with ERS-2 data and improved the extraction with a combination of the two datasets. Sichangi et. al (Sichangi et al., 2016) achieved different $R^{2}$ values varying from 0.41 to 0.96 . The used method in this study is simple and less time consuming compared to the other studies.
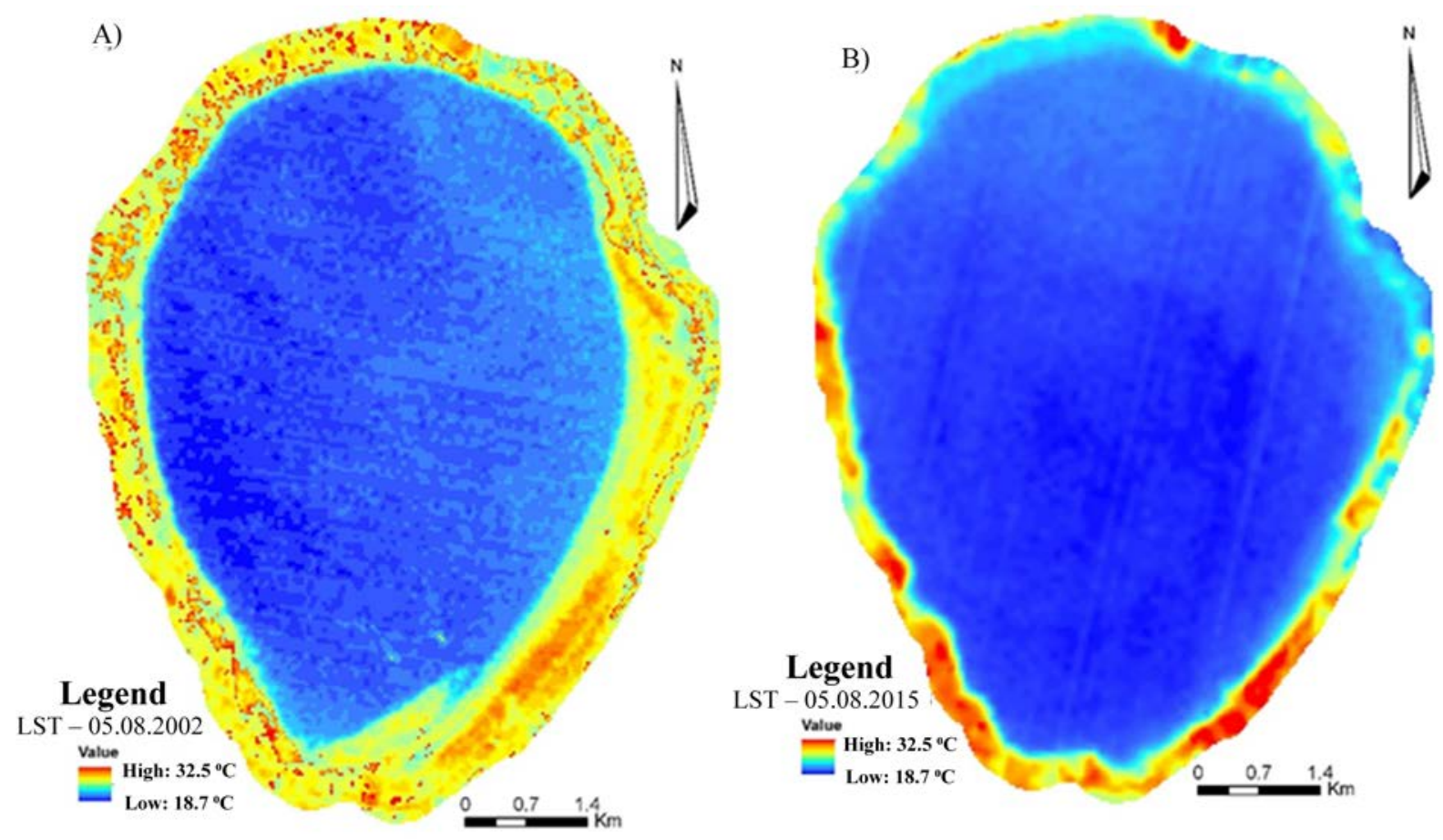

Figure 8. LST maps a) Landsat 7- 2002; b) Landsat 8 - 2015 


\section{CONCLUSION}

Water bodies are an essential part of nature and the environment. Their monitoring is a crucial part of their welfare and protection. Over the past ten years, many advanced remote sensing instruments have been initiated that collect information that can be used for monitoring different aspects of drought. In this study, using remote sensed images monitoring of Dojran Lake has been made. The results were compared with the results of the water level gauging station.

In conclusion, we can bring up that remote sensed images are a rich source for monitoring the water body changes. This kind of monitoring can be useful in cases like the Dojran Lakes case where there is not enough available data on the water level changes. According to the previous researches, the biggest problem for Dojran sustainable water resources management is the lack of data exchange between the sharing countries. The ecological catastrophe of the Dojran Lake has been known for several years. In ecological security frames, it has been known that one of the sharing countries did not respect the contract made by the two parties. It has been established that this disagreement has caused an ecological threat to the lake leading to lowering the water level, the tourism in the area, and has caused health issues as well. Thus, the new approaches to long-term water planning and management that incorporate principles of sustainability and equity are necessary for lowering the conflicts over water rights, and especially to avoid ecological and environmental catastrophes that may affect the sharing countries.

This study is a simple case of how remote sensing data and techniques can help in planning and decision making related not only to the water body changes but also to the environmental problems. For future studies, as an addition to the Landsat data, data from Sentinel-2 satellite with higher spatial resolution can be included in water bodies and drought monitoring researchers. 


\section{REFERENCES}

Artis, D. A., \& Carnahan, W. H. (1982). Survey of emissivity variability in thermography of urban areas. Remote Sensing of Environment, 12(4), 313-329.

Avdan, U., \& Jovanovska, G. (2016). Algorithm for Automated Mapping of Land Surface Temperature Using LANDSAT 8 Satellite Data. Journal of Sensors. doi:Artn 1480307

Bogning, S., Frappart, F., Blarel, F., Niño, F., Mahé, G., Bricquet, J.-P., . . . Paiz, M.-C. (2018). Monitoring Water Levels and Discharges Using Radar Altimetry in an Ungauged River Basin: The Case of the Ogooué. Remote Sensing, 10(2), 350.

Bonacci, O., Popovska, C., \& Geshovska, V. (2015). Analysis of transboundary Dojran Lake mean annual water level changes. Environmental Earth Sciences, 73(7), 3177-3185. doi:10.1007/s12665-014-3618-6

Dojran-info. http://www.dojran-info.com/.

Elkollaly, M., Khadr, M., \& Zeidan, B. (2017). Drought analysis in the Eastern Nile basin using the standardized precipitation index. Environmental Science and Pollution Research, $1-15$.

Gao, Z., Gao, W., \& Chang, N.-B. (2011). Integrating temperature vegetation dryness index (TVDI) and regional water stress index (RWSI) for drought assessment with the aid of LANDSAT TM/ETM+ images. International Journal of Applied Earth Observation and Geoinformation, 13(3), 495-503.

Gleason, C. J., \& Smith, L. C. (2014). Toward global mapping of river discharge using satellite images and at-many-stations hydraulic geometry. Proceedings of the National Academy of Sciences, 111(13), 4788-4791.

Gleason, C. J., Smith, L. C., \& Lee, J. (2014). Retrieval of river discharge solely from satellite imagery and at-many-stations hydraulic geometry: Sensitivity to river form and optimization parameters. Water Resources Research, 50(12), 9604-9619.

Isaya Ndossi, M., \& Avdan, U. (2016). Application of open source coding technologies in the production of land surface temperature (LST) maps from Landsat: A PYQGIS plugin. Remote Sensing, 8(5), 413.

Keshavarz, M. R., Vazifedoust, M., \& Alizadeh, A. (2014). Drought monitoring using a Soil Wetness Deficit Index (SWDI) derived from MODIS satellite data. Agricultural Water Management, 132, 37-45. doi:10.1016/j.agwat.2013.10.004

Khadr, M. (2017). Temporal and spatial analysis of meteorological drought characteristics in the upper Blue Nile river region. Hydrology Research, 48(1), 265-276.

Li, P., Jiang, L. G., \& Feng, Z. M. (2014). Cross-Comparison of Vegetation Indices Derived from Landsat-7 Enhanced Thematic Mapper Plus ( ETM plus ) and Landsat-8 Operational Land Imager ( OLI) Sensors. Remote Sensing, 6(1), 310-329. doi:10.3390/rs6010310

Matlievska, М. ОСВРТ НА ПРОЕКТОТ “СПАС НА ДОJРАНСКОТО ЕЗЕРО”.

McFeeters, S. K. (1996). The use of the normalized difference water index (NDWI) in the delineation of open water features. International Journal of Remote Sensing, 17(7), 14251432.

Munyaneza, O., Wali, U. G., Uhlenbrook, S., Maskey, S., \& Mlotha, M. J. (2009). Water level monitoring using radar remote sensing data: Application to Lake Kivu, central Africa. Physics and Chemistry of the Earth, Parts A/B/C, 34(13-16), 722-728. 
Nakmuenwai, P., Yamazaki, F., \& Liu, W. (2017). Automated Extraction of Inundated Areas from Multi-Temporal Dual-Polarization RADARSAT-2 Images of the 2011 Central Thailand Flood. Remote Sensing, 9(1), 78.

Nemani, R. R., \& Running, S. W. (1989). Estimation of Regional Surface-Resistance to Evapotranspiration from Ndvi and Thermal-Ir Avhrr Data. Journal of Applied Meteorology, 28(4), 276-284. doi:Doi 10.1175/1520-0450(1989)028<0276:Eorsrt>2.0.Co;2

Omute, P., Corner, R., \& Awange, J. L. (2012). The use of NDVI and its derivatives for monitoring Lake Victoria's water level and drought conditions. Water resources management, 26(6), 1591-1613.

Orhan, O., Ekercin, S., \& Dadaser-Celik, F. (2014). Use of Landsat Land Surface Temperature and Vegetation Indices for Monitoring Drought in the Salt Lake Basin Area, Turkey. Scientific World Journal. doi:Artn 142939 10.1155/2014/142939

Sabins, F. F. (1997). Remote Sensing: Principles and Interpretation. 92, 754-754.

Sichangi, A. W., Wang, L., Yang, K., Chen, D., Wang, Z., Li, X., . . . Kuria, D. (2016). Estimating continental river basin discharges using multiple remote sensing data sets. Remote Sensing of Environment, 179, 36-53.

Sigdel, M., \& Ikeda, M. (2010). Spatial and temporal analysis of drought in Nepal using standardized precipitation index and its relationship with climate indices. Journal of Hydrology and Meteorology, 7(1), 59-74.

Sobrino, J. A., \& Raissouni, N. (2000). Toward remote sensing methods for land cover dynamic monitoring: application to Morocco. International Journal of Remote Sensing, 21(2), 353-366. doi:Doi 10.1080/014311600210876

USGS. https://www.usgs.gov/.

Ustin, S. L. (2004). Remote sensing of environment: State of the science and new directions. Remote Sensing of Natural Resources Management and Environmental Monitoring.

Zhang, X. S., Reed, J., Wagner, B., Francke, A., \& Levkov, Z. (2014). Lateglacial and Holocene climate and environmental change in the northeastern Mediterranean region: diatom evidence from Lake Dojran (Republic of Macedonia/Greece). Quaternary Science Reviews, 103, 51-66. doi:10.1016/j.quascirev.2014.09.004 